\title{
KOMPOSISI DAN POLA MUSIM IKAN HASIL TANGKAPAN DI PERAIRAN TEGAL JAWA TENGAH
}

\section{Composition and Season Pattern of Catched Fish in Tegal Waters of Central Java}

\author{
Oleh: \\ Mohammad Imron ${ }^{1 *}$, Kusnandar ${ }^{2}$, Didin Komarudin ${ }^{1}$ \\ ${ }^{1}$ Departemen Pemanfaatan Sumberdaya Perikanan, Fakultas Perikanan dan Ilmu Kelautan, Institut \\ Pertanian Bogor, Indonesia \\ ${ }^{2}$ Fakultas Perikanan dan Ilmu Kelautan Universitas Pancasakti,Tegal, Indonesia \\ *Korespondensi penulis: mohammadim@apps.ipb.ac.id
}

\begin{abstract}
ABSTRAK
Pemanfaatan sumber daya ikan harus berdasarkan efisiensi dan asas keberlanjutan. Efisiensi merupakan usaha untuk memaksimumkan hasil penangkapan, dengan menggunakan sumber daya seminimal mungkin. Efisiensi penangkapan dapat didukung dengan diketahuinya pola musim atau waktu terbaik menangkap suatu sumberdaya ikan. Informasi mengenai pola musim penangkapan juga sangat dibutuhkan oleh manajer perikanan baik pemerintah maupun swasta dalam melakukan pengaturan agar upaya eksploitasi terhadap sumberdaya ikan dilakukan secara bijak dan berkelanjutan. Penelitian ini bertujuan untuk menentukan komposisi hasil tangkapan dan pola musim penangkapan ikan di perairan Tegal. Penelitian dilakukan di TPI Larangan dan TPI Suradadi Kabupaten Tegal, pada bulan Maret 2019, dengan metode survei. Hasil penelitian menunjukkan Produksi ikan dominan selama 5 tahun (2016-2019) di perairan Tegal adalah teri jawa (3.753,9 ton), selanjutnya rebon $(1.305,4$ ton), ikan tembang (542,4 ton), teri nasi (355,2 ton), kembung (116,1 ton), pepetek ( 87,3 ton), dan cumi-cumi sebanyak 18,7 ton. Puncak musim penangkapan ikan teri nasi adalah bulan Februari. Puncak musim ikan teri jawa adalah bulan Juni. Puncak musim ikan pepetek adalah bulan Januari. Puncak musim ikan kembung terjadi pada bulan Januari. Puncak musim ikan tembang terjadi pada bulan Januari. Puncak musim penangkapan udang rebon terjadi pada bulan Februari. Puncak musim cumi-cumi terjadi pada bulan April.
\end{abstract}

Kata kunci: komposisi hasil tangkapan, pengelolaan, pola musim penangkapan

\begin{abstract}
Fish resources utilization must be based on efficiency and sustainability principles. Efficiency is an attempt to maximize fishing yields, by using the minimum possible resources. Fishing efficiency can be supported by knowing the season pattern or the best time to catch a fish resource. Fisheries managers both government and private sector need information regarding fishing season patterns in making arrangements so that exploitation of fish resources is carried out wisely and sustainably. This study aims to determine composition of catch and fishing season pattern in Tegal waters. The research was conducted at TPI Larangan and TPI Suradadi, Tegal Regency, in March 2019, using survey method. Results showed that dominant fish production for 5 years (2016-2019) in Tegal waters was anchovies'teri jawa' (3,753.9 tons), then 'rebon' (1,305.4 tons), 'tembang' fish (542.4 tons), anchovies-'teri nasi' (355, 2 tons), 'kembung' fish (116.1 tons), 'pepetek' (87.3 tons), and 18.7 tons of squid. Peak season for anchovy-teri nasi' fishing is February. Peak season for Javan anchovy is June. Peak season for 'pepetek' fish is January. Peak season for 'kembung' fish occurs in January. Peak season for 'tembang' occurs in January. Peak season for catching 'rebon' shrimp occurs in February. Peak season for squid occurs in April.
\end{abstract}

Key words: catch composition, fishing season patterns, management 


\section{PENDAHULUAN}

Nelayan di Kabupaten Tegal pada umumnya hanya memanfaatkan sumber daya ikan di sekitar perairan Tegal saja, yang merupakan bagian kecil dari Laut Jawa. Kapal yang digunakan untuk melaut umumnya berukuran kecil, yakni kisarannya sekitar 3-10 GT. Jenis alat tangkap yang digunakan beraneka ragam, diantaranya adalah payang, mini purse seine dan gillnet. Selama periode lima tahun terakhir (2015-2019), jenis alat tangkap yang cenderung mengalami kenaikan adalah payang dan purse seine, sedangkan yang mengalami penurunanan adalah alat tangkap gillnet.

Hasil tangkapan nelayan Tegal didominasi oleh ikan-ikan yang banyak hidup di perairan pantai ( $<12$ mil). Jenis ikan hasil tangkapan tersebut antara lain ikan teri nasi (Stolephorus commerson), teri jawa (Stolephorus indicus), tembang (Sardinella fimbriata), kembung (Rastrelliger sp), pepetek (Photopectoralis bindus), cumi-cumi (Loligo sp.), dan udang rebon (Acetes indicus). Saat ini nelayan biasa mendaratkan ikan hasil tangkapan di dua Tempat Pelelangan Ikan (TPI), yaitu TPI Larangan dan TPI Suradadi.

Nelayan Tegal pada umumnya mengoperasikan alat tangkap secara one day fishing. Nelayan pergi ke fishing ground, lalu melakukan penangkapan ikan, dan pulang kembali ke fishing base, seluruh proses tersebut dilakukan dalam satu hari saja. Saat ini, jumlah alat tangkap yang ada di TPI Langanan dan TPI Suradadi mengalami fluktuasi. Unit penangkapan ikan yang banyak terdapat di TPI Langanan adalah payang gemplo dan purse seine atau disebut puring, sedangkan alat tangkap yang banyak terdapat di TPI Suradadi adalah jabur dan kerikit.

Pola musim penangkapan beberapa jenis ikan mengalami perubahan dan pergeseran di beberapa wilayah di Indonesia. Pola musim ikan tidak jarang berubah dan dapat membingungkan nelayan. Biasanya nelayan tidak melakukan kajian secara empiris, dan mengikuti perubahan pola musim penangkapan yang terjadi begitu saja. Pergeseran waktu dan musim penangkapan bisa jadi disebabkan oleh perilaku penangkapan nelayan itu sendiri, yang melakukan eksploitasi lebih dan kurang memperhatikan daya dukung sumber daya ikan di alam. Manajemen terhadap perubahan pola musim dapat meningkatkan efisiensi penangkapan, sehingga nelayan dapat melakukan persiapan yang baik sebelum melakukan operasi penangkapan. Oleh karena itu, informasi mengenai prediksi musim puncak dan pola musim penangkapan secara lebih pasti sangat diperlukan.

Pengelolaan perikanan tangkap saat ini mulai menjadi prioritas semua stakeholder dengan tujuan untuk keberlangsungan sumber daya ikan yang terdapat di perairan Tegal. Pemanfaatan sumber daya ikan yang berkelanjutan hanya dapat dilakukan apabila berorientasi pada daya dukung lingkungan dan kelestarian sumber daya ikan. Informasi tentang komposisi produksi, produktivitas, dan musim penangkapan ikan di Kota Tegal masih sangat minim, padahal informasi tersebut sangat diperlukan sebagai dasar dalam menentukan strategi pemanfaatan dan pengelolaan ikan di Kabupaten Tegal. Kajian serupa yang pernah dilakukan masih terbatas pada satu jenis alat tangkap saja atau satu spesies ikan saja, sehingga tidak memberikan gambaran yang holistik. Penelitian ini melakukan kajian terhadap beberapa alat tangkap yang dominan di perairan Tegal, sehingga diharapkan dapat memberikan gambaran yang lebih komprehensif. Penelitian ini bertujuan untuk menentukan komposisi hasil tangkapan dan pola musim penangkapan ikan di perairan Tegal. Hasil penelitian ini diharapkan dapat bermanfaat untuk menentukan strategi pengelolaan perikanan ikan dengan mengutamakan kelestarian sumberdaya ikan dan lingkungan perairan.

\section{METODE PENELITIAN}

Penelitian ini dilakukan di TPI Larangan dan TPI Suradadi Kabupaten Tegal, pada bulan Juni 2020. Metode penelitian yang digunakan adalah metode survei, dengan melakukan wawancara terhadap 20 nelayan, kepala dan staf Tempat Pelelangan Ikan (TPI) Larangan dan TPI Surodadi. Data yang diperoleh berupa data produksi hasil tangkapan, komposisi jenis hasil tangkapan dan data lainnya. 
Data yang diperoleh, selanjutnya diolah di Laboratorium Teknologi Penangkapan Ikan, Departemen Pemanfaatan Sumberdaya Perikanan, Fakultas Perikanan dan Ilmu Kelautan, Institut Pertanian Bogor. Lokasi penelitian selama penelitian, disajikan pada Gambar 1.

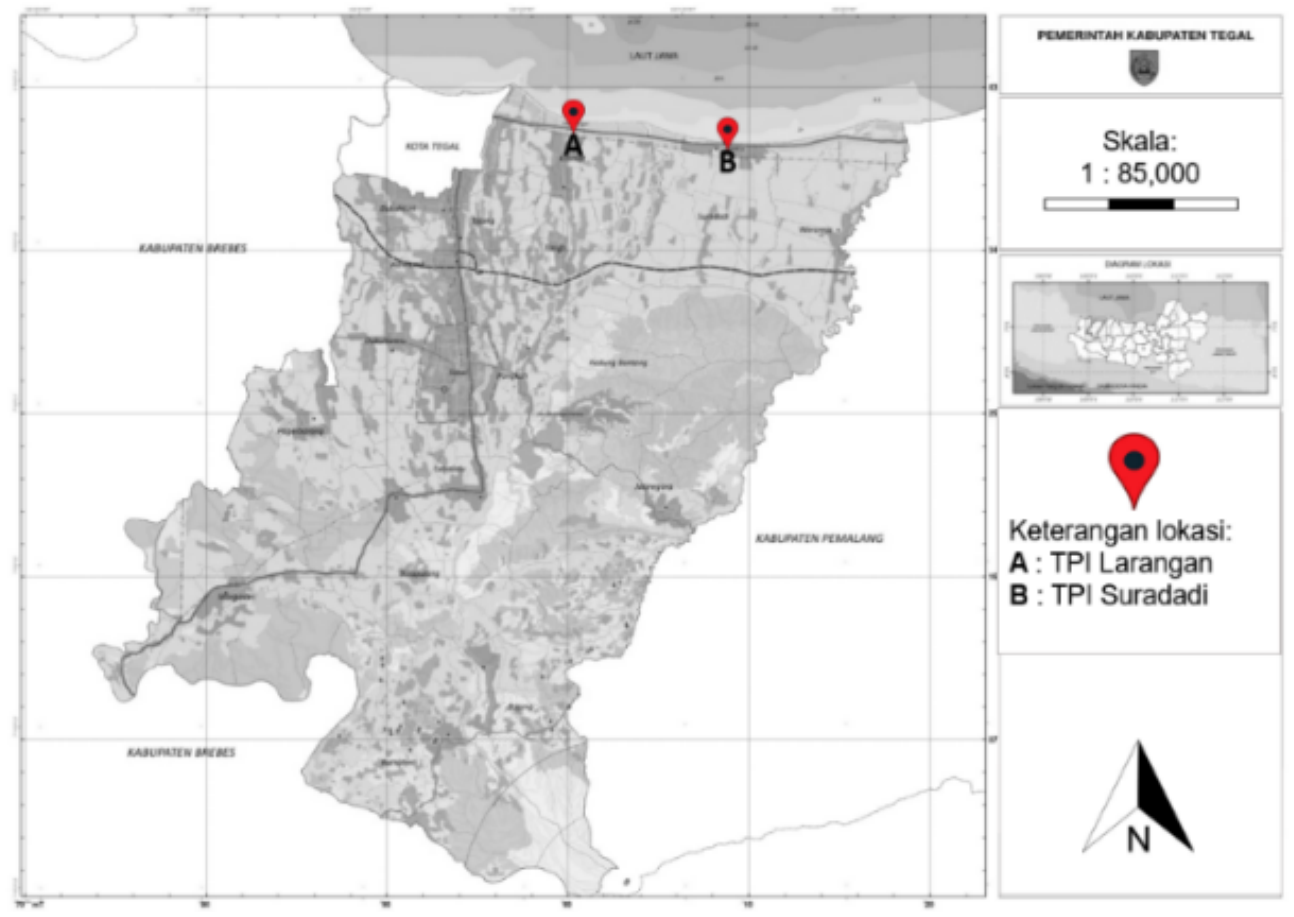

Gambar 1 Peta Lokasi Penelitian

Data yang dikumpulkan pada penelitian ini terdiri atas data primer meliputi jenis alat tangkap, komposisi jenis dan produksi hasil tangkapan, yang diperoleh dari hasil wawancara dan observasi lapang terhadap aktivitas pendaratan ikan di TPI Larangan dan TPI Suradadi pada bulan Juni 2020. Data sekunder yang dikumpulkan berupa data produksi bulanan ikan yang didaratkan di kedua TPI tersebut. Data sekunder yang dikumpulkan mulai dari tahun 2015 hingga tahun 2019. Data komposisi ikan hasil tangkapan dominan dianalisis menggunakan analisis deskriptif, yakni dengan menganalisis data ikan hasil tangkapan yang dominan tertangkap dari tahun 2015-2019.

Indeks musim penangkapan merupakan nilai indeks yang menunjukkan tingkat musim suatu jenis ikan pada suatu lokasi penangkapan, berdasarkan satuan waktu tertentu. Indeks musim digunakan untuk menentukan waktu yang tepat dalam melakukan operasi penangkapan ikan sehingga tingkat keuntungan yang diperoleh nelayan dapat maksimal dengan sumber daya ikan tetap lestari. Data pola musim penangkapan dianalisis dengan menggunakan analisis deret waktu terhadap data bulanan hasil tangkapan alat tangkap purse seine dan payang selama lima tahun. Kedua alat tangkap tersebut merupakan penghasil dominan hasil tangkapan ikan yang didaratakan, terutama di PPP Langangan. Tahapan selanjutnya dilanjutkan dengan menghitung rata-rata bergerak (moving average). Tahapan perhitungan pola musim berdasarkan Purwasasmita (1993), adalah sebagai berikut:

1) Menghitung CPUE (catch per unit effort) per bulan dan rata-rata CPUE bulanan dalam setahun

$\hat{\mathrm{U}}=\frac{1}{m} \sum_{i=1}^{m} U_{i}$

Dimana: $\quad U$ : CPUE rata-rata bulanan per tahun (ton/trip)

$U_{i}$ : CPUE per bulan (ton/trip)

m: 12 (Jumlah bulan dalam setahun) 
2) Menghitung $U_{p}$, yaitu rasio $U_{i}$ terhadap $U$

3) Menghitung indeks musim (IM)

$$
I M_{i}=\frac{1}{t} \sum_{i=1}^{t} U_{p}
$$

Dimana: IMi: Indeks musim ke-i $t$ : Jumlah tahun dari data

4) Jika nilai $I M_{i}$ tidak $1.200 \%$ (12 bulan $\mathrm{x} 100 \%$ ), maka digunakan rumus berikut untuk menyesuaikannya:

$I M S_{i}=\frac{1200}{\sum_{i=1}^{m} I M_{1}} x I M_{i}$

Dimana: IMSi: Indeks musim ke-i yang disesuaikan

5) Jika terdapat nilai ekstrim pada $U_{P}$, maka nilai $U_{p}$ tidak digunakan dalam perhitungan nilai indeks musim (IM), maka yang digunaan adalah nilai $M_{d}$ dari $I M$ tersebut. Apabila jumlah nilai $M d$ tidak sebesar $1.200 \%$, maka perlu dilakukan penyesuaian dengan formula sebagai berikut:

$I^{\prime M M D S} S_{i}=\frac{1200}{\sum_{i=1}^{m} M d_{i}} x M d_{i}$

Dimana: $\quad I M M D S i$ : Indeks musim dengan median ke-i yang disesuaikan

6) Kriteria penentuan musim adalah indeks musim lebih jika nilai indeks lebih dari 1 (atau $>100 \%$ ) atau di atas rata-rata; bukan musim jika nilai indeks musim kurang dari 1 (atau $<100 \%$ ). Jika nilai IM sama dengan $1(=100 \%)$, maka dapat disimpulkan ikan dalam kondisi normal atau berimbang.

Menurut Zulkarnaen et al. (2012), musim penangkapan dibagi menjadi tiga kategori, yaitu musim puncak, musim sedang dan musim paceklik. Berikut merupakan penggolongan musim penangkapan (Tabel 1).

Tabel 1 Kategori Indeks Musim Penangkapan

\begin{tabular}{lll}
\hline No & Nilai IMP & Kategori Musim \\
\hline 1 & $<50 \%$ & Paceklik \\
2 & $50 \% \leq \mathrm{IMP}<100 \%$ & Sedang \\
3 & $\geq 100 \%$ & Puncak \\
\hline
\end{tabular}

Sumber: Zulkarnaen et al. (2012).

\section{HASIL DAN PEMBAHASAN}

\section{Produksi Ikan di Perairan Tegal}

Produksi ikan mengalami fluktuasi sepanjang tahun 2015 (Statistik Perikanan Kabupaten Tegal Tahun 2015). Hal tersebut karena adanya pengaruh musim penangkapan yaitu musim banyak ikan, musim sedang ikan dan musim kurang ikan. Gambar 2 menunjukkan bahwa produksi tertinggi berada pada bulan April dan Juni untuk teri nasi, sedangkan produksi terendah terjadi pada bulan Agustus dan September untuk teri jawa dan teri nasi. Secara umum, hasil tangkapan ikan teri jawa paling dominan dibanding ikan lainnya. Dominasi teri jawa sebagai hasil tangkapan terbanyak, terjadi di setiap bulan dibandingkan ikan lainnya. 


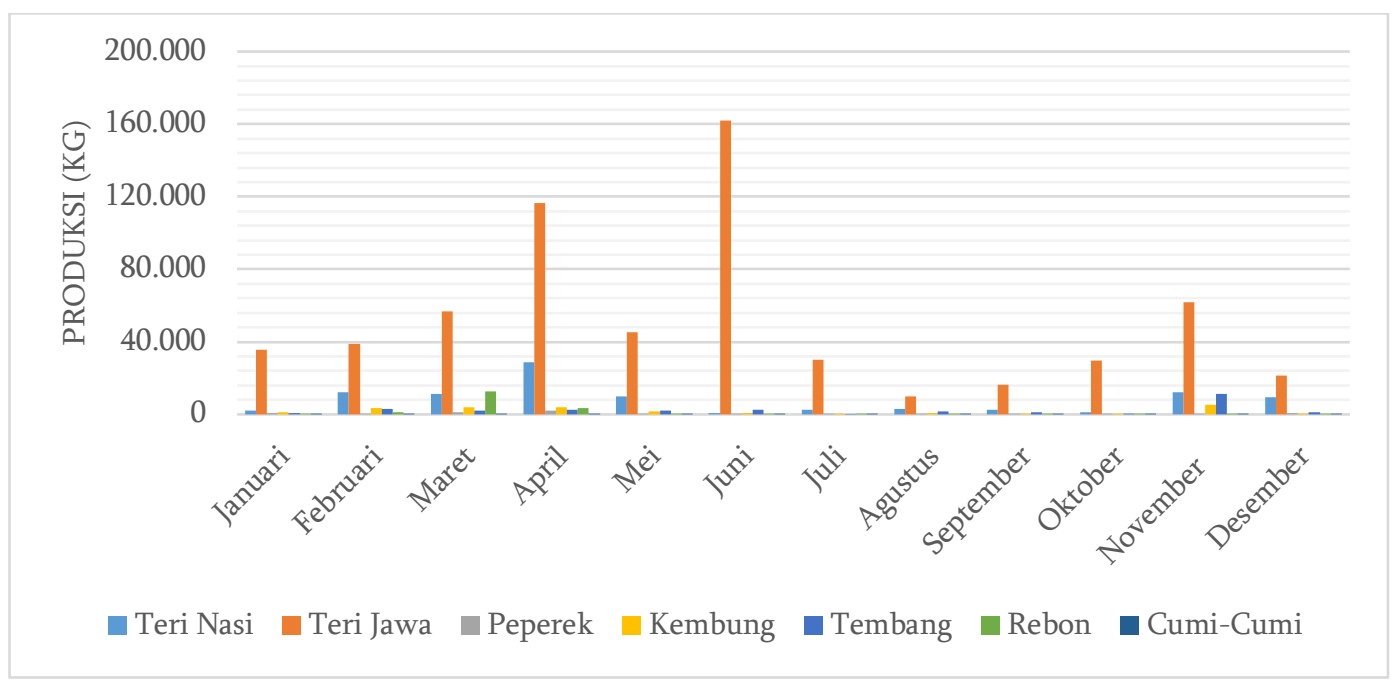

Gambar 2 Komposisi Hasil Tangkapan Tahun 2015

Produksi ikan hasil tangkapan utama pada tahun 2016 secara umum masih mengalami fluktuasi (Statistik Perikanan Kabupaten Tegal Tahun 2016). Jumlah hasil tangkapan teri jawa masih mendominasi disetiap bulannya. Musim puncak teri jawa pada tahun 2016 terjadi pada bulan Juni hingga Agustus. Sama hal nya dengan tahun 2015, musim ikan pada tahun 2016 mulai mengalami peningkatan dari bulan Januari hingga Mei. Ikan-ikan lain seperti teri nasi, kembung, tembang dan rebon mengalami hasil tangkapan tertinggi, dibanding bulan lainnya. Bahkan, untuk udang rebon pada bulan Maret dan April, hasil tangkapannya paling banyak, melebihi ikan-ikan lainnya. Hal tersebut tidak terjadi pada tahun 2015. Secara lebih lengkap, produksi ikan pada tahun 2016 dapat dilihat pada Gambar 3.

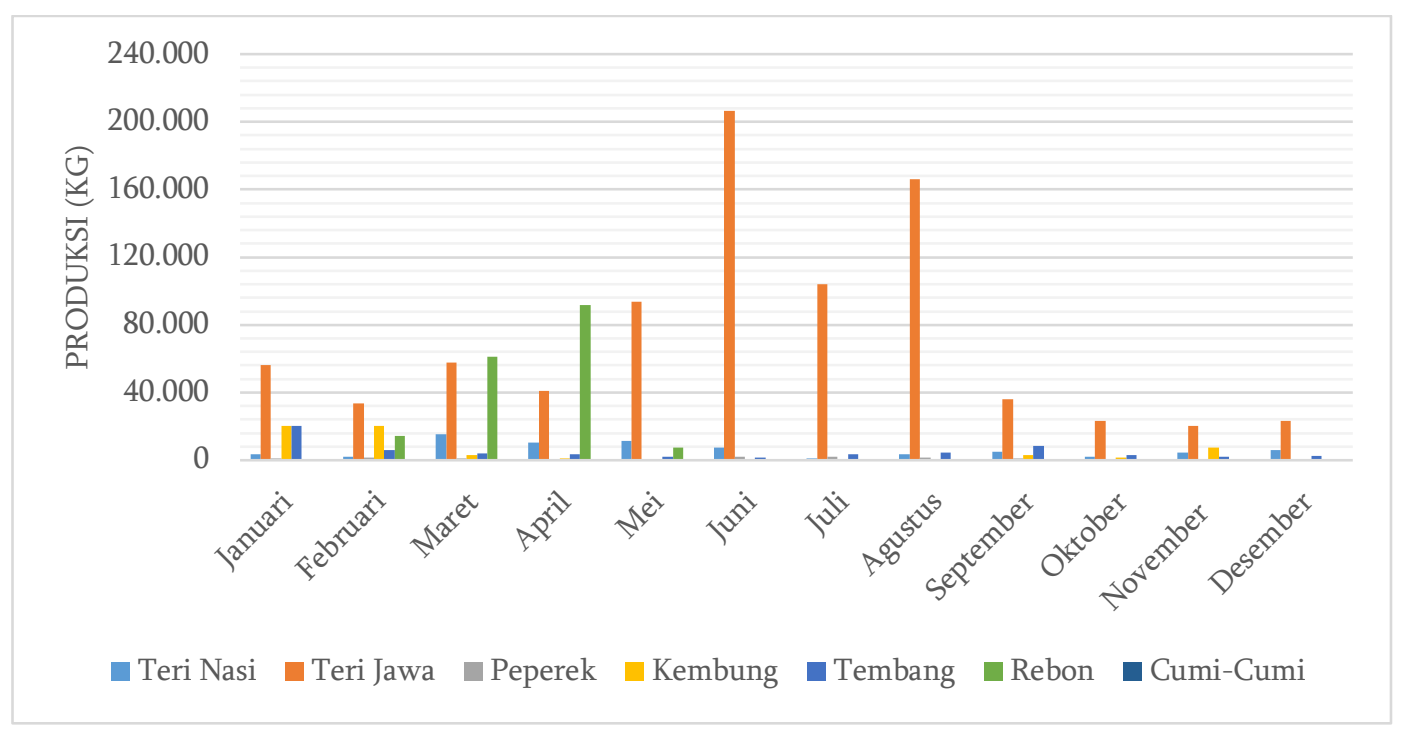

Gambar 3 Komposisi Hasil Tangkapan Tahun 2016

Produksi ikan pada tahun 2017 masih didominasi oleh teri jawa (Statistik Perikanan Kabupaten Tegal Tahun 2017). Teri jawa mengalami puncak penangkapan mulai dari bulan Januari hingga Juli, selanjutnya hasil tangkapan berfluktuasi dan cenderung menurun mulai Agustus hingga Desember. Sama halnya dengan dua tahun sebelumnya, ikan-ikan lain banyak tertangkap mulai dari Januari hingga April. Adapun khusus untuk rebon, terjadi puncak penangkapan pada bulan Maret, dengan produksi tertinggi dibandingkan ikan lainnya, yaitu mencapai 314,3 ton. Secara lebih lengkap, produksi ikan tahun 2017, dapat dilihat pada Gambar 4. 


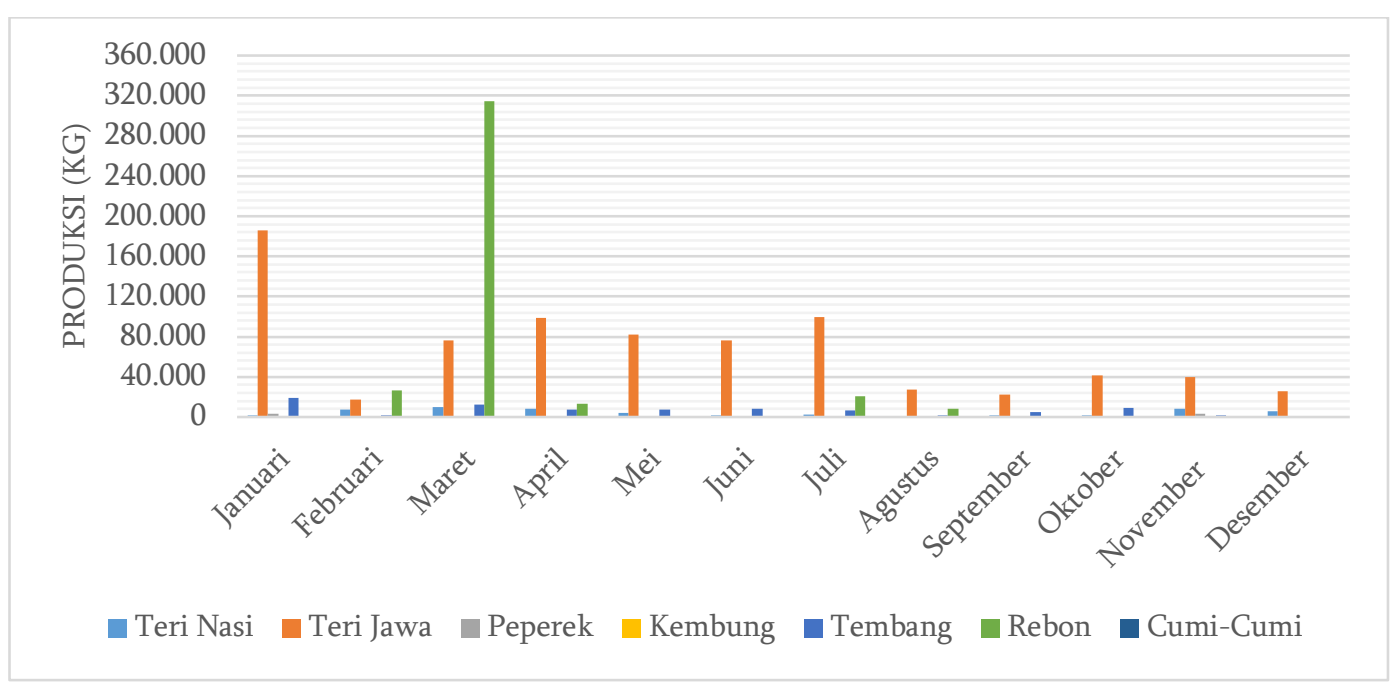

Gambar 4 Komposisi Hasil Tangkapan Tahun 2017

Pada tahun 2018 produksi ikan hampir merata sepanjang tahun (Statistik Perikanan Kabupaten Tegal Tahun 2018). Mulai dari Januari hingga Desember, ikan banyak tertangkap dari perairan Tegal. Khusus untuk teri jawa, mulai dari bulan Maret hingga Juli, hasil tangkapannya terus meningkat, dan hampir mendominasi, menjadi hasil tangkapan terbanyak di sepanjang tahun. Hanya saja, sama dengan tahun sebelumnya hasil tangkapan rebon mengalami peningkatan mulai Februari hingga Maret. Bahkan pada bulan Maret udang rebon merupakan hasil tangkapan tertinggi, jauh mengungguli ikan lain dengan nilai produksi sebesar 362,01 ton. Secara lebih jelas, produksi ikan pada tahun 2018 dapat dilihat pada Gambar 5.

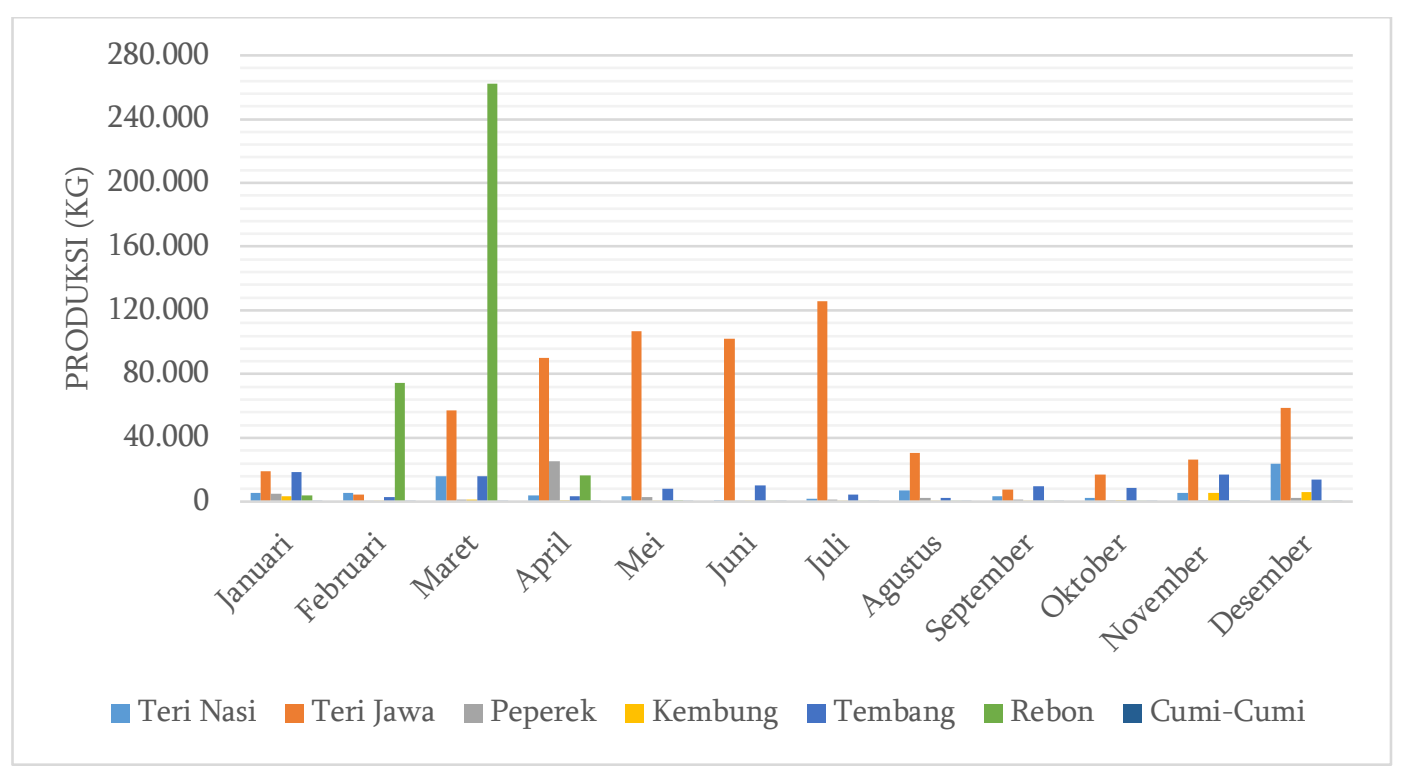

Gambar 5 Komposisi Hasil Tangkapan Tahun 2018

Produksi ikan pada tahun 2019 merupakan yang tertinggi jika dibanding 4 tahun kebelakang (Statistik Perikanan Kabupaten Tegal Tahun 2015). Ikan tembang mengalami peningkatan produksi yang mencolok dibandingkan tahun sebelumnya. Musim tembang berfluktuasi mulai Januari dan mengalami puncaknya pada bulan April hingga Mei, pada bulan Juni hingga September mengalami penurunan, dan hasil tangkapan tembang kembali meningkat mulai bulan Oktober hingga November. Begitupun dengan udang rebon, hasil tangkapannya relatif tinggi pada bulan Februari hingga April, selanjutnya menurun dan meningkat kembali pada buln September dan Oktober. Walau demikian, 
hasil tangkapan ikan teri jawa tetap mendominasi hampir sepanjang tahun, dan mengalami puncaknya pada bulan Juni. Secara lebih terperinci, produksi ikan pada tahun 2019 disajikan pada Gambar 6.

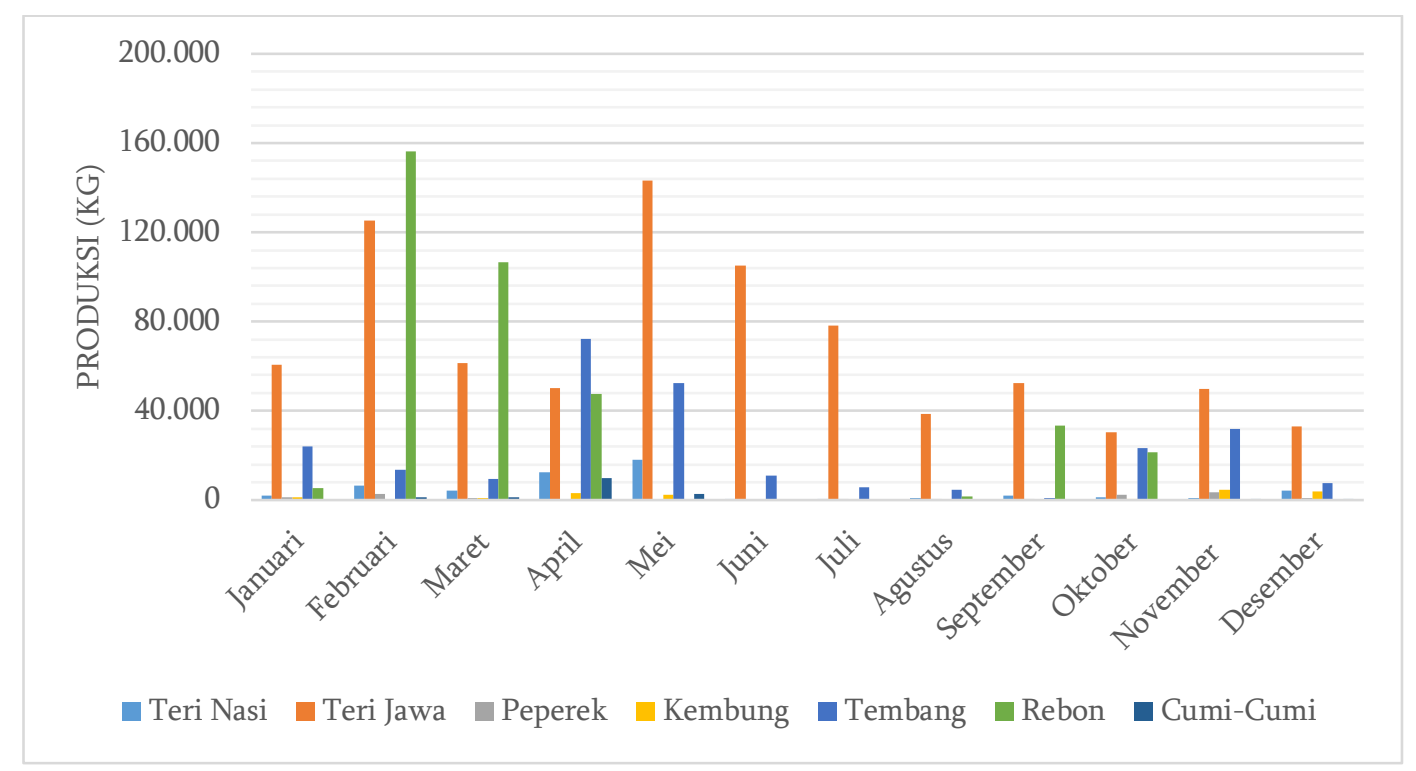

Gambar 6 Komposisi Hasil Tangkapan Tahun 2019

Berdasarkan Gambar 7, selama periode 5 tahun terakhir yaitu tahun 2015-2019 produksi ikan dominan yang didaratkan dari perairan Tegal sebesar 6.179,2 ton. Ikan dominan tersebut yaitu, teri nasi, teri jawa, pepetek, kembung, tembang, rebon, dan cumi-cumi. Secara berurutan, hasil tangkapan terbanyak selama 5 tahun terakhir didominasi oleh teri jawa (3.753,9 ton), selanjutnya rebon $(1.305,4$ ton), ikan tembang (542,4 ton), teri nasi (355,2 ton), kembung (116,1 ton), pepetek ( 87,3 ton), dan cumi-cumi sebanyak 18,7 ton. Produksi teri nasi mengalami fluktuasi selama 5 tahun terakhir, dengan puncak produksi pada tahun 2016 kemudian menurun dan meningkat kembali pada tahun 2019. Adapun rebon, mulai mengalami peningkatan produksi sejak tahun 2016, meningkat kembali pada tahun 2017 dan relatif stabil hingga tahun 2019.

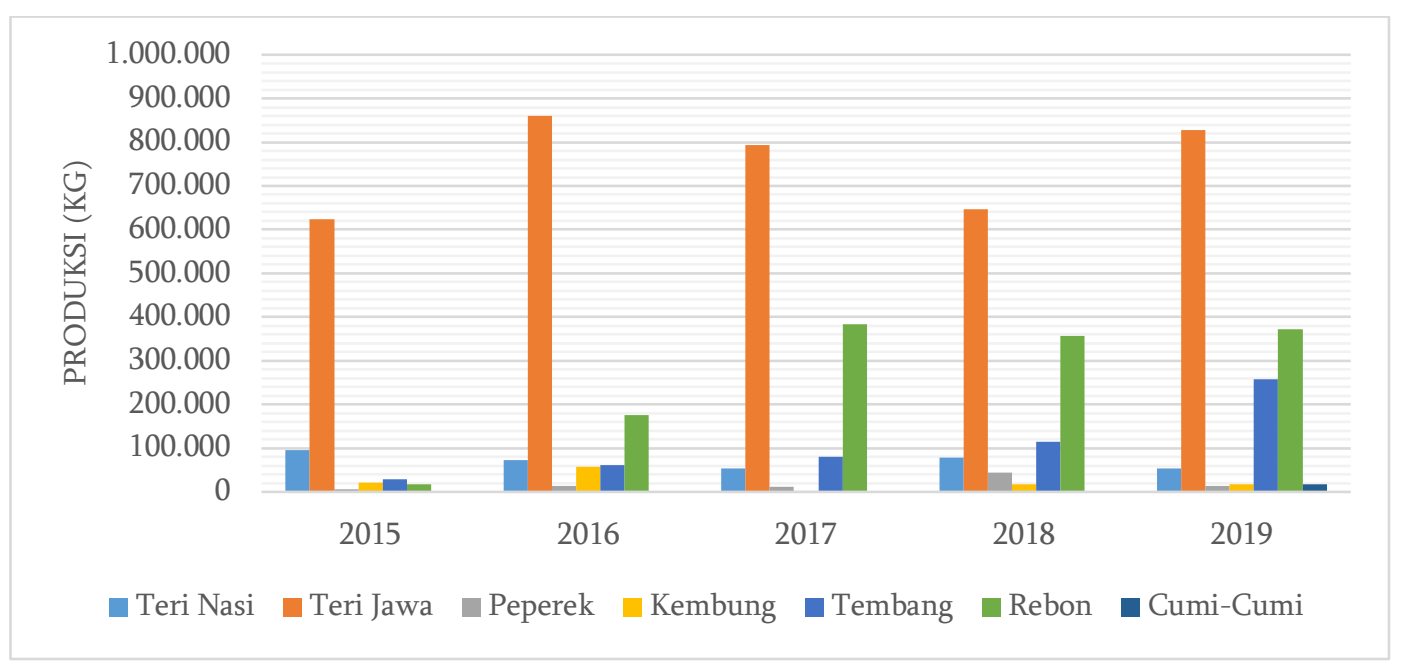

Gambar 7 Produksi Penangkapan Ikan Dominan di Perairan Tegal pada Tahun 2015-2019

\section{Musim Penangkapan Ikan di Perairan Tegal}

Berdasarkan indeks musim penangkapan teri nasi (Gambar 8) terlihat bahwa musim puncak penangkapan ikan tersebut terjadi pada bulan Februari (197,3\%), sedangkan musim paceklik terjadi 
pada bulan Juli (44,1\%). Upaya penangkapan dapat dioptimalkan pada nilai indeks musim $>100 \%$. Musim penangkapan teri nasi dapat mulai bulan September, November, Desember, Februari, April, dan Mei.

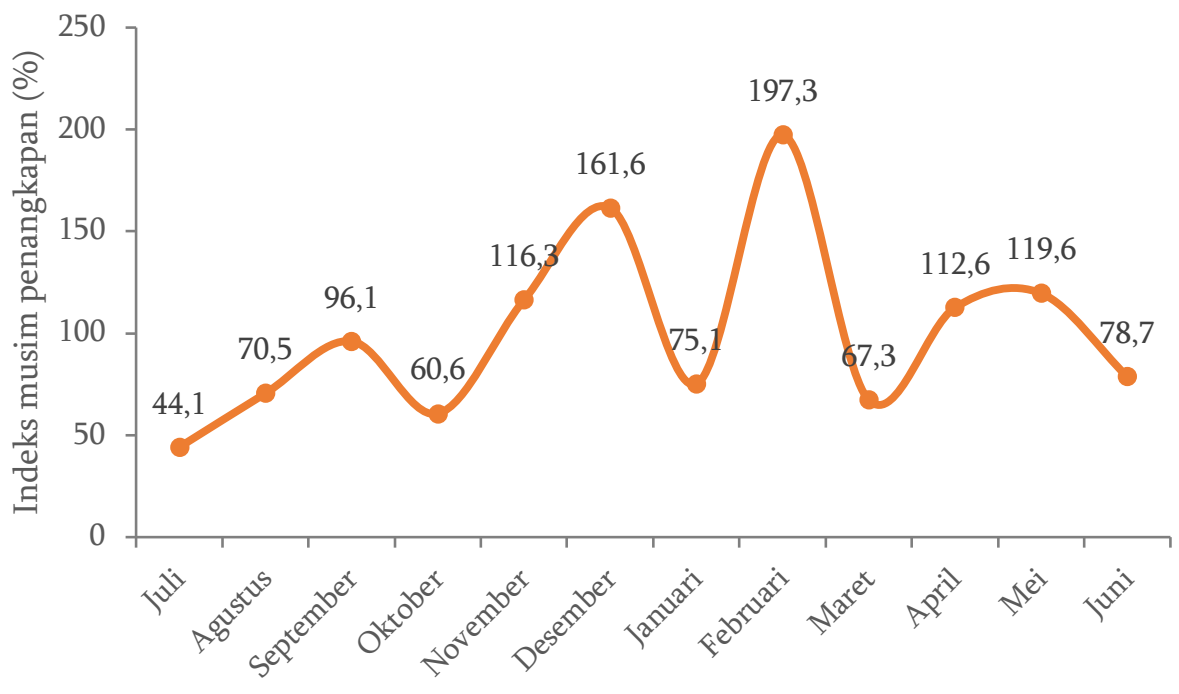

Gambar 8 Musim Penangkapan Ikan Teri Nasi

Teri jawa merupakan ikan dominan yang banyak tertangkap di perairan Tegal, dibandingkan jenis ikan lainnya. Berdasarkan Gambar 9 terlihat bahwa musim puncak penangkapan ikan teri jawa terjadi pada bulan Juni yaitu mencapai $283,3 \%$, sedangkan musim paceklik terjadi yaitu pada bulan Maret, dan Desember. Berdasarkan indeks musim penangkapan pada Gambar 9, penangkapan teri jawa dapat dilakukan pada bulan Januari, Mei, Juni, dan Juli, dengan nilai indeks musim masing-masing adalah sebesar $130,9 \%, 120,7 \%, 283,3 \%$, dan $175,5 \%$.

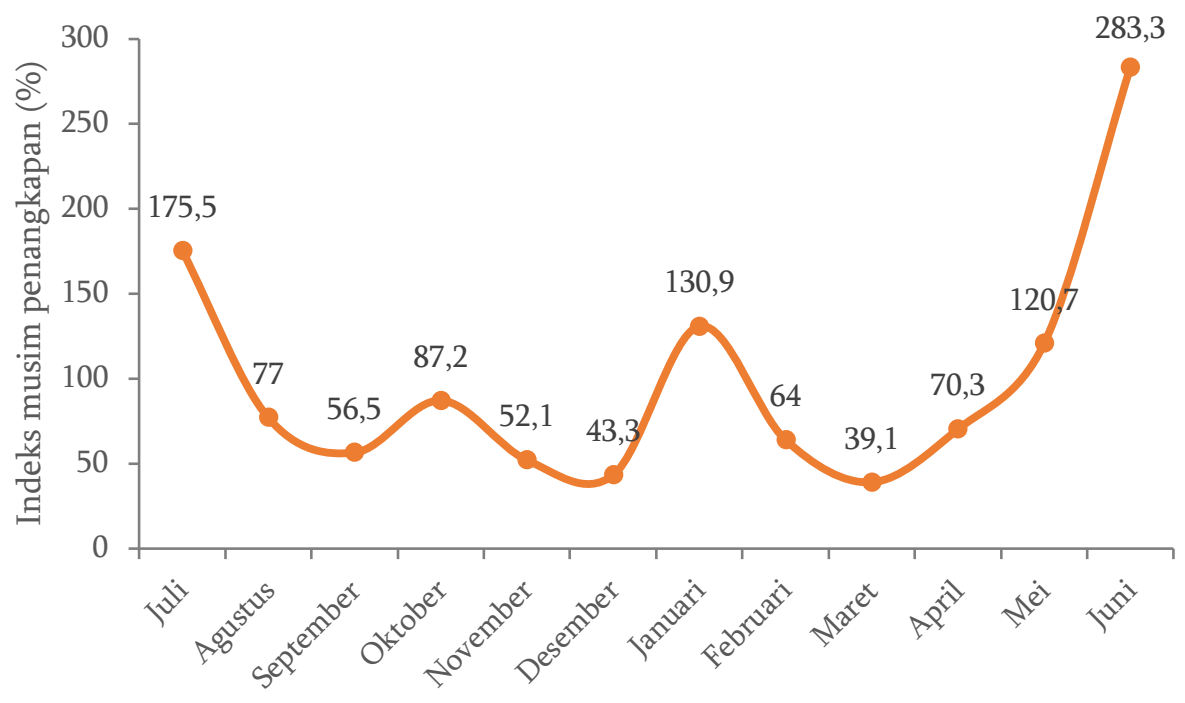

Gambar 9 Musim Penangkapan Ikan Teri Jawa

Berdasarkan Gambar 10 terlihat bahwa musim puncak penangkapan pepetek terjadi pada bulan Januari, sedangkan musim paceklik terjadi pada bulan Maret. Walau demikian, bulan Desember hingga April merupakan waktu terbaik menangkap ikan pepetek. Karena pada periode waktu tersebut terdapat puncak produksi. Apabila melihat fluktuasi indeks musim yang terjadi, pada bulan Juli dan September 
juga masih layak dilakukan operasi penangkapan untuk ikan pepetek ini, karena nilai indeks musim penangkapannya masih diatas $100 \%$.

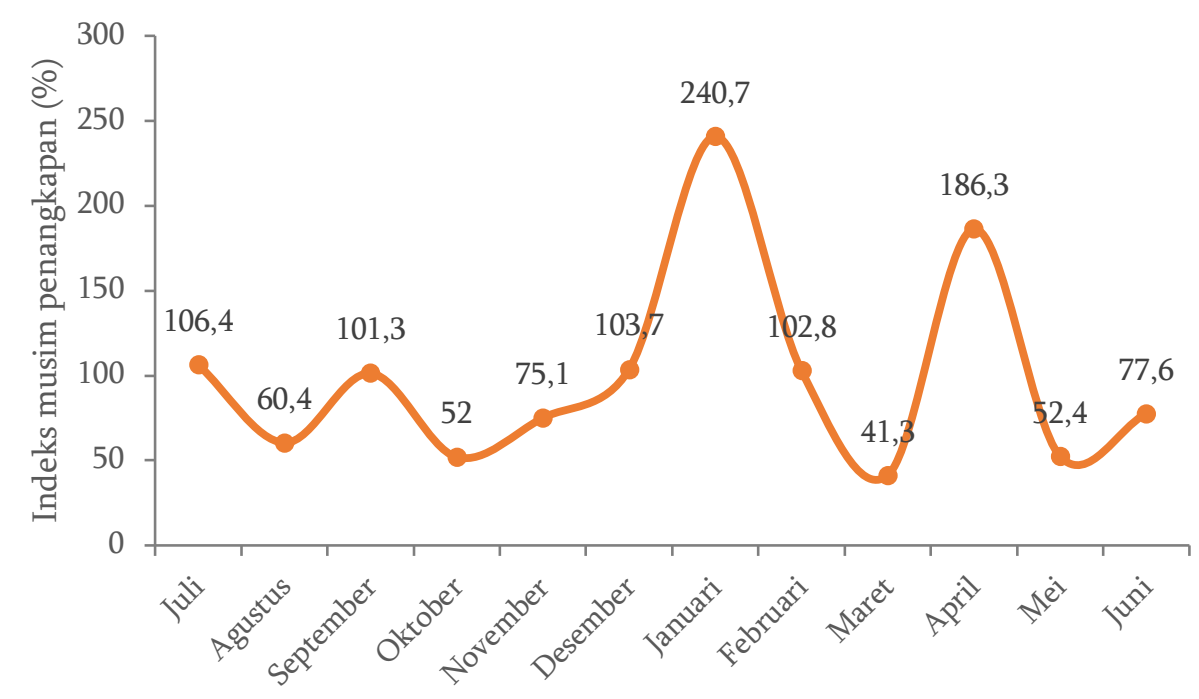

Gambar 10 Musim Penangkapan Ikan Pepetek

Berdasarkan Gambar 11 terlihat bahwa musim puncak penangkapan kembung terjadi pada bulan Januari dengan indeks musim penangkapan sebesar $371,2 \%$, sedangkan musim paceklik terjadi pada bulan Juli dengan indeks musim penangkapan sebesar 7,5\%. Berdasarkan Gambar 11 tersebut maka dapat disimpulkan bahwa pola musim penangkapan ikan kembung terjadi pada bulan Oktober sampai Februari, dan bulan Juni. Adapun musim sedikit ikan, terjadi pada bulan Juli-September dan Maret-Mei.

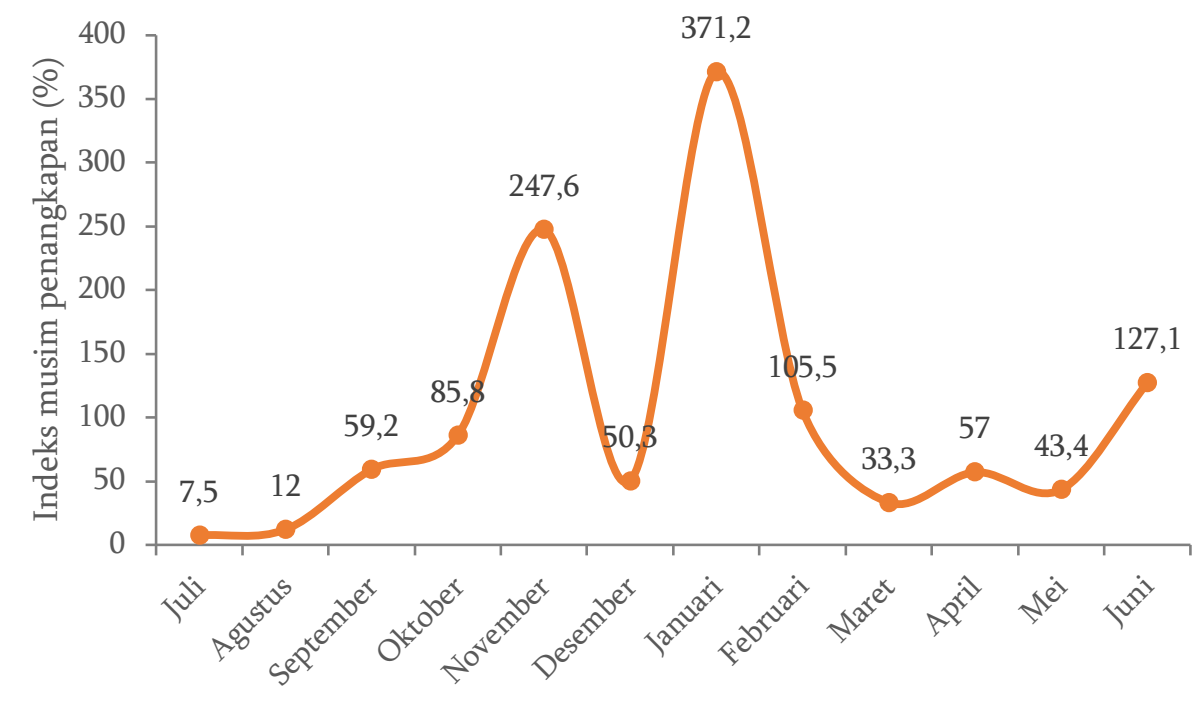

Gambar 11 Musim Penangkapan Ikan Kembung

Puncak musim penangkapan ikan tembang terjadi pada bulan Januari. Adapun paling sedikit terjadi pada bulan Desember. Berdasarkan Gambar 12 penangkapan ikan tembang dapat dioptimalkan pada bulan Juni, September, dan puncaknya pada bulan Januari. Adapun musim sedikit ikan terjadi pada Juli, Agustus, Desember, dan Maret. 


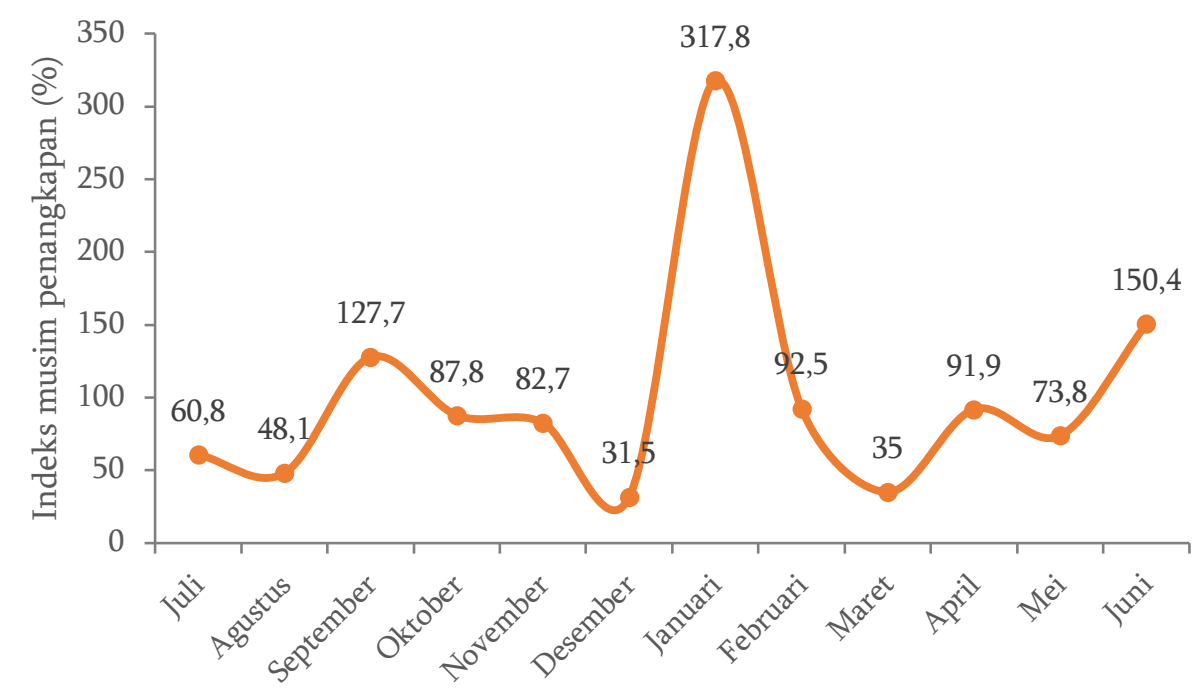

Gambar 12 Musim Penangkapan Ikan Tembang

Berdasarkan Gambar 13 terlihat bahwa musim puncak penangkapan udang rebon terjadi pada bulan Februari, dengan indeks musim penangkapan sebesar 519,7\%. Adapun musim paceklik terjadi pada bulan Januari, Mei hingga Desember. Dapat disimpulkan bahwa pola musim penangkapan udang rebon pada bulan Februari sampai April. Pada musim puncak tersebut, terjadi jumlah udang yang sangat banyak, hal ini ditunjukan dengan nilai indeks musim penangkapan yang jauh lebih besar dari 100\%.

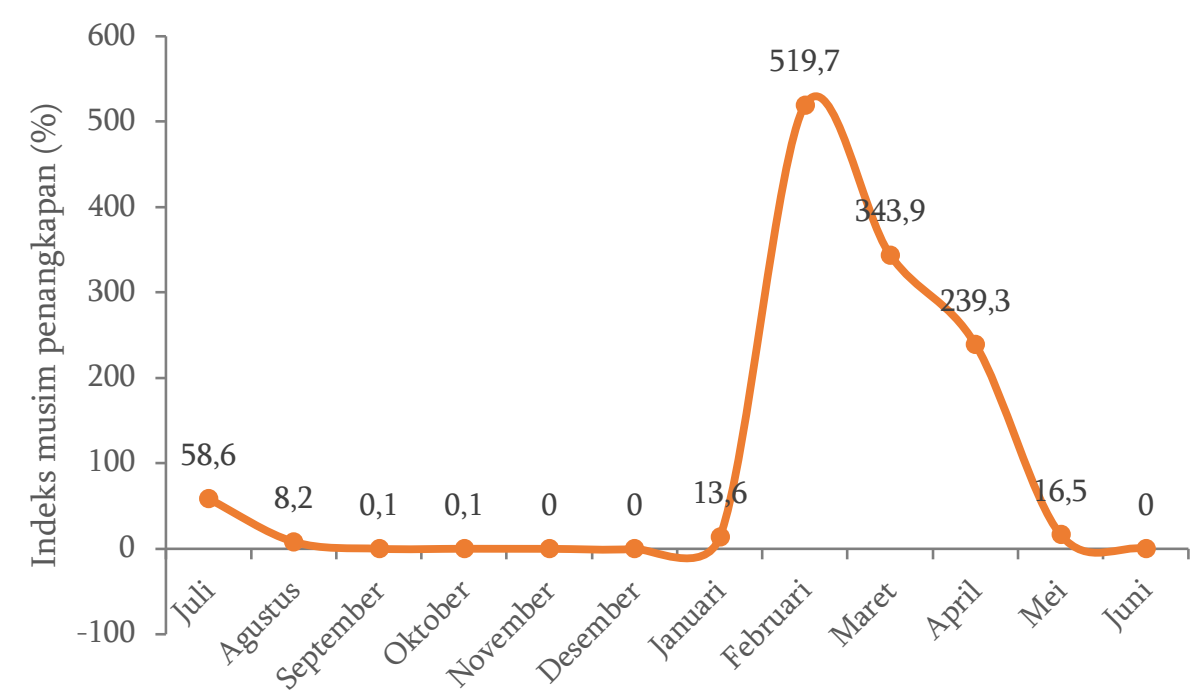

Gambar 13 Musim Penangkapan Udang Rebon

Cumi-cumi merupakan salah satu ikan ekonomis penting yang ada di Perairan Tegal. Berdasarkan indeks musim, diperoleh bahwa puncak musim penangkapan cumi terjadi mulai dari bulan April dan Juli. Puncak musim terjadi pada bulan April, dengan indeks musim penangkapan sebesar 353,7\%, sedangkan musim paling sedikit cumi-cumi yaitu pada bulan Agustus dan September, dengan masing-masing indeks musim sebesar 6,3 dan $9 \%$. Secara lebih jelas, indeks musim penangkapan cumicumi di perairan Tegal dapat dilihat pada Gambar 14. 


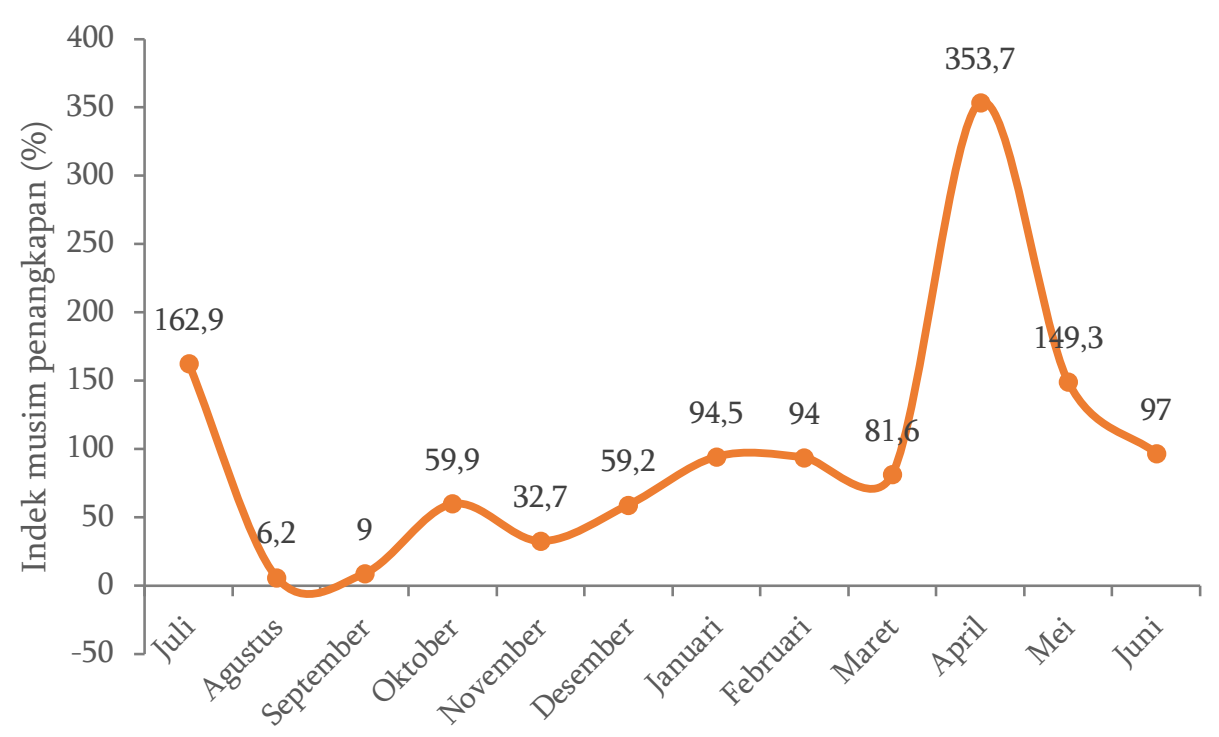

Gambar 14 Musim Penangkapan Cumi-cumi

Sebagian besar nelayan di Kabupaten Tegal mengoperasikan beragam alat tangkap untuk menangkap ikan dengan jarak masih terbilang tidak jauh dari pantai, walaupun demikian untuk alat tangkap purse seine ukuran besar bisa melakukan penangkapan hingga ke Natuna, Selat Makassar, dan Laut Flores (Suharso 2006). Nelayan yang menangkap ikan hingga ke luar dari perairan Tegal, antara lain menggunakan alat tangkap cantrang dan purse seine. Menurut Ernawati et al. 2011, daerah penangkapan cantrang di sekitar perairan timur Sumatera dan perairan Bangka Belitung serta di perairan Laut Jawa di selatan Kalimantan. Untuk jenis alat tangkap mini purse seine dan payang, pada umumnya hanya dioperasikan di perairan Tegal dan sekitarnya. Nelayan biasanya melakukan operasi penangkapan dengan sistem one day fishing. Hasil tangkapan ikan yang dioperasikan oleh nelayan yang menggunakan unit penangkapan mini purse seine dan payang pada umumnya adalah jenis ikan pelagis. Namun demikian ada juga jenis ikan demersal seperti pepetek yang tertangkap juga dengan menggunakan jaring purse seine. Hal ini disebabkan pengoperasian jaring mini purse seine kadang dilakukan pada perairan yang tidak terlalu dalam sehingga bagian bawah jaring mini purse seine tersebut sampai ke dasar perairan. Ada enam jenis hasil tangkapan dominan yang hampir setiap hari dan bulannya tertangkap dengan kedua alat tangkap tersebut. Ke-enam jenis ikan tersebut adalah: teri nasi (Stolephorus commersoni), teri jawa (Stolephorus insularis), pepetek (Leiognathidae bindus), tembang (Sardinella fimbriata), rebon (Acetes indicus), dan cumi-cumi (Loligo sp.).

Sumberdaya ikan yang merupakan hasil tangkapan dominan nelayan di Kabupaten Tegal, diataranya adalah teri nasi (Stolephorus commersoni), teri jawa (Stolephorus insularis), pepetek (Leiognathidae bindus), tembang (Sardinella fimbriata), rebon (Acetes indicus), dan cumi-cumi (Loligo sp.). Penyebaran jenis-jenis ikan tesebut hampir ada di seluruh periaran Indonesia, tentu dengan jumlah yang beragam (Saanin 1984, Mayrita 2010). Menurut Nursinar et al. (2015), penyebaran cumicumi (Loligo sp.) di seluruh perairan Indonesia hampir merata, yaitu dari barat Sumatera, Selat Malaka, Laut Jawa, Laut Banda, perairan Maluku dan Arafura. Sumberdaya ikan tersebut termasuk kedalam sumberdaya yang tinggal di perairan pantai, sehingga memang menjadi target penangkapan nelayan artisanal.

Pola musim puncak penangkapan pada setiap spesies dominan yang tertangkap di perairan Tegal bervariasi. Walau demikian untuk ikan pepetek, kembung, dan tembang terjadi musim pun penangkapan yang sama yaitu pada bulan Januari. Adapun teri nasi dan udang rebon, sama-sama mengalami musim puncak penangkapan pada bulan Februari. Secara umum, musim penangkapan pada bulan Januari adalah ikan teri jawa, pepetek, kembung, tembang. Bulan Februari merupakan musim penangkapan untuk ikan teri nasi, pepetek, kembung, dan rebon. Bulan Maret merupakan musim 
penangkapan untuk rebon saja. Bulan April merupakan musim penangkapan untuk teri nasi, pepetek, dan rebon. Bulan Mei merupakan musim penangkapan untuk teri nasi dan teri jawa. Bulan Juni merupakan musim penangkapan untuk teri jawa, pepetek, kembung, dan tembang. Bulan Juli merupakan musim penangkapan teri jawa saja. Bulan September merupakan musim penangkapan teri nasi, pepetek, dan tembang. Bulan November merupakan musim penangkapan teri nasi. Adapun bulan Desember merupakan musim penangkapan teri nasi dan pepetek. Secara lebih jelas, musim penangkapan ikan dominan pada setiap bulannya dapat dilihat pada Tabel 2 .

Tabel 2 Sebaran Musim Penangkapan Ikan Dominan pada setiap Bulan

\begin{tabular}{lcccccccccccc}
\hline $\begin{array}{l}\text { Jenis } \\
\text { ikan }\end{array}$ & Jan & Feb & Mar & Apr & Mei & Jun & Jul & Ags & Sep & Okt & Nov & Des \\
\hline Teri nasi & & $\sqrt{ }$ & & $\sqrt{ }$ & $\sqrt{ }$ & & & & $\sqrt{ }$ & & $\sqrt{ }$ & $\sqrt{ }$ \\
Teri jawa & $\sqrt{ }$ & & & & $\sqrt{ }$ & $\sqrt{ }$ & $\sqrt{ }$ & & & & & \\
Pepetek & $\sqrt{ }$ & $\sqrt{ }$ & & $\sqrt{ }$ & & $\sqrt{ }$ & & & $\sqrt{ }$ & & & $\sqrt{ }$ \\
Kembung & $\sqrt{ }$ & $\sqrt{ }$ & & & & $\sqrt{ }$ & & & & $\sqrt{ }$ & & \\
Tembang & $\sqrt{ }$ & & & & & $\sqrt{ }$ & & & $\sqrt{ }$ & & & \\
Rebon & & $\sqrt{ }$ & $\sqrt{ }$ & $\sqrt{ }$ & & & & & & & & \\
\hline
\end{tabular}

Pemanfaatan sumber daya ikan harus berdasarkan efisiensi dan asas keberlanjutan. Efisiensi merupakan usaha untuk memaksimumkan hasil tangkapan, dengan menggunakan sumber daya seminimal mungkin. Selama ini, nelayan melakukan operasi penangkapan dengan data base musim penangkapan yang tidak tercatat dengan baik. Musim penangkapan biasanya diketahui berdasaran perkiraan dan perhitungan pengalaman saja. Oleh karena itu, informasi mengenai pola musim berdasarkan data produksi sangat mutlak diperlukan. Efisiensi penangkapan dapat didukung dengan diketahuinya pola musim atau waktu terbaik menangkap suatu sumberdaya ikan. Informasi mengenai pola musim penangkapan juga sangat dibutuhkan oleh manajer perikanan baik pemerintah maupun swasta dalam melakukan pengaturan agar upaya eksploitasi terhadap sumber daya ikan dilakukan secara bijak dan berkelanjutan.

Hasil tangkapan alat tangkap di perairan Tegal terdiri dari rebon (Meretrix spp.), teri (Stolephorus spp.), tiga waja (Otolithes sp.), petek (Leognathus spp.), kembung (Rastrelligersp.), tanjan (Sardinella sp.). Jenis ikan lain yang beberapa tahun silam masih ditangkap dan pada 2-3 tahun terakhir sudah hilang atau sulit didapat dan diantaranya adalah bulu ayam (Setipinna spp.), beloso (Saurida spp.), manyung (Arius spp.), sembilang (Plotosus spp.), kerapu (Epinephelus spp.), kerong-kerong (Therapon spp), gerot-gerot (Pristipoma spp.), biji nangka (Parupeneus spp.), kapas-kapas (Gerres spp.), ikan lidah (Paralichthys olivaceus), ikan sebelah (Psettodidae), udang krosok (Metapenaeus monoceros), udang windu (Penaeus monodon), dan udang pacet (Penaeus semisulcatus). Hampir bisa dipastikan hampir semua biota laut yang hidup di perairan pantai akan tertangkap oleh operasi purse seine dan payang, mulai dari ikan, krustasea, dan moluska. Pada musim puncak hasil tangkapan utama alat tangkap ini adalah teri nasi (50\%), teri jawa (30\%) dan selebihnya ikan campuran.

Produksi ikan di perairan Kabupaten Tegal pada periode 2016-2019 mengalami fluktuasi, namun cenderung meningkat. Secara berurutan, total produksi ikan dominan dari tahun 2016-2019 adalah 792,7 ton (2015); 1.241,1 ton (2016); 1.327,1 ton (2017); 1.259,4 ton (2018); dan 1.558,9 ton (2019). Berdasarkan data 5 tahunan tersebut peneliti menduga puncak penangkapan terjadi pada tahun 2019 merupakan siklus 5 tahunan. Puncak musim berikutnya akan terjadi kembali pada tahun 2024 mendatang.

Faktor musim sangat berpengaruh terhadap hasil tangkapan ikan di perairan Tegal. Berdasarkan kondisi oseanografis, biasanya musim puncak berada pada musim timur dimana kondisi perairan relatif tenang. Pada musim timur, bertiup angin muson timur yang memungkinkan terjadinya transport ekman yang membawa air permukaan menjauhi pantai di daerah Utara Jawa. Hal tersebut 
mengakibatkan kekosongan dengan anomali tinggi permukaan laut (TPL) yang rendah. Akibatnya, terjadi perpindahan air di area kolom perairan menuju ke permukaan air (upwelling). Fenomena upwelling ini konsisten terjadi pada suhu permukaan laut (SPL) yang rendah pada periode tersebut. Rendahnya suhu permukaan laut menyebabkan densitas di permukaan laut meningkat dan memindahkan massa air dari permukaan ke kolom perairan. Sehingga terjadi peningkatan konsentrasi klorofil-a yang menyebabkan tingginya ketersediaan makanan bagi ikan-ikan dalam tingkat konsumen primer.

\section{KESIMPULAN DAN SARAN}

Produksi ikan dominan selama 5 tahun (2016-2019) di perairan Tegal adalah teri jawa (3.753,9 ton), selanjutnya rebon (1.305,4 ton), ikan tembang (542,4 ton), teri nasi (355,2 ton), kembung (116,1 ton), pepetek (87,3 ton), dan cumi-cumi sebanyak 18,7 ton.

Puncak musim penangkapan teri nasi adalah bulan Februari, upaya penangkapannya bisa dilakukan antar bulan November hingga Mei. Puncak musim teri jawa adalah bulan Juni, upaya maksimum penangkapan dapat dilakukan pada bulan Janurai, Mei hingga Juli. Puncak musim ikan pepetek adalah bulan Januari, sedangkan upaya penangkapan dapat dilakukan pada bulan Desember hingga April, bulan Juli dan September. Pucak musim kembung terjadi pada bulan Januari, sedangkan musim penangkapannya dapat dilakukan mulai bulan Oktober hingga Februari, dan bulan Juni. Puncak musim ikan tembang terjadi pada bulan Januari, sedangkan musim penangkapannya dapat dilakukan pada bulan Januari, Februari, April, Juni dan September. Puncak musim penangkapan udang rebon terjadi pada bulan Februari, sedangkan musim penangkapannya terjadi pada bulan Februari-April. Puncak musim cumi-cumi terjadi pada bulan April, sedangkan musim penangkapannya dapat dilakukan pada bulan Januari hingga Juli.

Upaya penangkapan terhadap sumberdaya ikan dominan di perairan Tegal harus disesuaikan dengan puncak musim yang terjadi. Hal ini dimaksudkan agar terjadi efisiensi dalam upaya penangkapan. Selain itu, pemerintah harus melakukan pengaturan terkait pemanfaatan sumber daya ikan dominan di perairan Tegal, dengan mengkaji indeks musim dengan tingkat kematangan gonad ikan. Agar pemanfaatan sumber daya ikan tersebut tetap memperhatikan kelestarian.

\section{UCAPAN TERIMA KASIH}

Ucapan terima kasih disampaikan kepada dan staf Dinas Perikanan dan Kelautan Kabupaten Tegal, TPI Larangan dan TPI Surodadi serta nelayan yang telah banyak membantu dalam penyediaan data yang mendukung penelitian ini.

\section{DAFTAR PUSTAKA}

Dinas Kelautan dan Perikanan Kabupaten Tegal. 2015. Statistik Perikanan Laut Tahun 2015. DKP Kabupaten Tegal. Jawa Tengah.

Dinas Kelautan dan Perikanan Kabupaten Tegal. 2016. Statistik Perikanan Laut Tahun 2016. DKP Kabupaten Tegal. Jawa Tengah.

Dinas Kelautan dan Perikanan Kabupaten Tegal. 2017. Statistik Perikanan Laut Tahun 2017. DKP Kabupaten Tegal. Jawa Tengah.

Dinas Kelautan dan Perikanan Kabupaten Tegal. 2018. Statistik Perikanan Laut Tahun 2018. DKP Kabupaten Tegal. Jawa Tengah. 
Dinas Kelautan dan Perikanan Kabupaten Tegal. 2019. Statistik Perikanan Laut Tahun 2019. DKP Kabupaten Tegal. Jawa Tengah.

Ernawati T. \& Atmadja SB. 2017. Produktivitas, komposisi hasil tangkapan dan daerah penangkapan jaring cantrang yang berbasis di PPP Tegalsari, Tegal. Jurnal Penelitian Perikanan Indonesia, 17(3): 193-200.

Hutabarat S. \& Evans SM. 1986. Kunci Identifikasi Zooplankton. Penerbit Universitas Indonesia (UIPress). Hutomo M, Burhanuddin, Djamali A, Martosewojo S. 1987. Sumberdaya ikan teri di Indonesia. Pusat Penelitian dan Pengembangan Oseanologi-LIPI. Seri Sumberdaya Alam. Jakarta. 80 hal.

Mayrita. 2010. Optimalisasi Pemanfaatan Sumberdaya Ikan Teri di Perairan Teluk Banten [Skripsi]. Bogor (ID): Fakultas Perikanan dan Ilmu Kelautan, Institut Pertanian Bogor.

Monintja D, Zulkarnaen R \& Mawardi W. 1994. Studi tentang kelimpahan ikan tembang (Sardinella fimbriata) di Perairan Pelabuhan Ratu (tahap I: recruitment dan fishing mortality) [Laporan Penelitian]. Bogor (ID): Fakultas Perikanan dan Ilmu Kelautan, Institut Pertanian Bogor. 104 hal.

Nontji A. 2005. Laut Nusantara. Jakarta (ID): Penerbit Djambatan.

Nursinar S, Sahami FM, Hamzah SN. 2015. Analisis dinamika populasi suntung (Loligo sp) di Perairan Teluk Tomini Desa Olimoo'o Kecamatan Batudaa Pantai. Gorontalo (ID): Fakultas Perikanan dan Ilmu Kelautan, Universitas Negeri Gorontalo. 60 hal.

Purwasasmita R. 1993. Musim Penangkapan Ikan Cakalang, Katsuwonus pelamis, dengan Kapal-Kapal Huhate dan Pengaruhnya Terhadap Peningkatan Produksi di Perairan Sekitar Sorong. Jurnal Penelitian Perikanan Laut. 79 : 1-13.

Puspitasari A. 2014. Identifikasi dan prevalensi cacing ektoparasit pada ikan kembung (Rastrelliger sp.) di Pelabuhan Perikanan Nusantara Brondong Lamogan [Skripsi]. Surabaya: Fakultas Perikanan dan Kelautan, Universitas Airlangga.

Saanin, 1984. Taksonomi dan Kunci Identifikasi Ikan Volume I dan II. Jakarta (ID): Bina Rupa Aksara.

Saputra SW, Solichin A, Akbar A. 2013. Analisis panjang-berat dan faktor kondisi pada udang rebon di Perairan Cilacap, Jawa Tengah. Journal of Management of Aquatic Resources. II (3): 161-169.

Suharso. 2006. Elastisitas produksi perikanan tangkap Kota Tegal [Tesis]. Semarang (ID): Program Pascasarjana, Universitas Diponegoro.

Syakila S. 2009. Studi dinamika stok ikan tembang (Sardinella fimbriata) di Perairan Teluk Palabuhanratu, Kabupaten Sukabumi, Provinsi Jawa Barat [Skripsi]. Bogor (ID): Fakultas Perikanan dan Ilmu Kelautan, Institut Pertanian Bogor.

Telleng A. 2010. Perikanan tangkap kembung (Rastrelliger sp.) di perairan sekitar Teluk Buyat. Jurnal Maritek. X (1): 51-59.

Wedjatmiko. 2007. Komposisi ikan petek (Leiognathidae) di perairan barat Sumatra. Jurnal Iktiologi Indonesia. VII (1): 9-14.

Wulandari DA. 2018. Morfologi, klasifikasi, dan sebaran cumi-cumi famili Lolinginidae. Jurnal Oseana. XLIII (2): 48-65.

Zulkarnaen, Wahyu RI, Sulistiono. 2012. Komposisi dan Estimasi Musim Penangkapan Ikan Pelagis dari Purse Seine yang Didaratkan di PPN Pekalongan Jawa Tengah. Jurnal Saintek Perikanan. 7 (2): 61-70. 